\title{
Al-Hidayah Boarding School: Deradicalized Terrorists
}

\author{
Novi Hendri ${ }^{1}$, Ridha Ahida $^{2}$, Ismail ${ }^{3}$ \\ \{novi.hendri@yahoo.co.id ${ }^{1}$,ridha.ahida@yahoo.co.id ${ }^{2}$,ismanov_2003@yahoo.com ${ }^{3}$ \} \\ Faculty Ushuluddin Adab and Dakwah, Institut Agama Islam Negeri (IAIN) Bukittinggi, Indonesia ${ }^{1,2}$ \\ Faculty of Syariah, Institut Agama Islam Negeri (IAIN) Bukittinggi, Indonesia ${ }^{3}$
}

\begin{abstract}
This pesantren is the only pesantren in Indonesia that can be used as a basis for deradicating radical understandings that deviate from Islamic teachings. The uniqueness of al-Hidayah Islamic boarding school compared to other pesantren is its local content which teaches de-radicalization to the students and also the community outside the pesantren. The al-Hidayah Islamic boarding school also introduced a more inclusive, accommodating and tolerant theology. The development of a democratic culture that receives support from pesantren needs to be sustained and further developed by strengthening theological reasons that can be used in deradicalization efforts.
\end{abstract}

Keywords. Pesantren, Deradicalisation, Former Terrorist

\section{Introduction}

Indonesia has recently been in a state of terrorism emergency. Starting from the commotion in Mako Brimob Depok until successive suicide bombings occurred in East Java and Riau. After identifying the culprit, why would anyone have the heart to commit suicide bombings by inviting their own children. Children who are supposed to enjoy playing and learning, for some reason actually go along to become martyrs of terrorism that killed many innocent people. Children of terrorists or those who are ensnared by radical understandings, actually become a very vulnerable group. As a result, it caused the acts of discrimination or even marginalize them, Though not all children of terrorist perpetrators will follow in the footsteps of their parents. They should get special guidance so that they are not trapped in terrorism networks and have a better future. This reality shows that religious education in both public schools and religious schools is more exclusive; religion is taught by denying the right to life of other religions, as if only his own religion is right and has the right to life, while other religions are wrong, lost and their right to live are threatened, both among the majority and minority. Religious education should be used as a vehicle to develop universal morality that exists in religions while developing inclusive and pluralist theology. Therefore, in the author's view, the deradicalization of Islamic education is a necessity. Efforts to deradicalize Islamic education in order to build multicultural-inclusive awareness to minimize Islamic radicalism need to be an in-depth study for experts and practitioners of Islamic education in Indonesia. 


\section{Discusion}

\subsection{Glance at al-Hidayah Islamic Boarding School}

The al-Hidayah boarding school was founded by al ustad Khairul Ghazali, who is a former terrorist, and this pesantren is devoted to the children of former terrorists, his anxiety is based on the number of children of terrorist families who have no future, they are ostracized in the midst of the community because the parents are engaged in terrorist movements, and if this is continued, it will be worrying, because their children who do not receive special attention will follow the footsteps of their parents to become terrorists, due to invitation from their father's friends to continue his father's struggle. The awareness of the Ustadz al-Ghazali founded the al-Hidayah pesentren, was his turmoil and anxiety that saw young children affected by social illness, and what further knocked his heart was seeing the future of the children of former terrorists, who did not know anythiing but should reach the future, considering that former terrorist children have a heavy mental burden in society because they are considered terrorist children.

As explained by one of the teachers at al-Hidayah Islamic Boarding School in the interview passage as follows: "Pesantren al-Hidayah was initiated by Ustad Al-Ghazali to educate terrorist children. This is where we educate them without distinguishing with other students, they play ball, learn with the concept of nature (life skills) they should not be excluded from the community, they are entitled to education as other children. We teach them about Islam so they don't hate other religions. We continue to monitor the children here, because we are worried about children's knowledge through the internet media (opening document files about terrorists) later after they enter high school. If now we can still provide an explanation so that they can succeed later. We as teachers here are sincere volunteers to help the government and society. "Preventative actions so far have been especially done against young people who fall into the category of at-risk groups such as children born in various conflict areas or children of former terrorists who tend to use violence. At a very young age, they are essentially in the formation of identity. They are young children, still unstable and easily affected by various environments in which they grow and develop.

Therefore it is necessary to establish a boarding school or a special school handling former terrorist children. Because early childhood is a golden period and the right period in the formation of character. So far the government only focused on arresting suspected terrorists and imprisoning them, but has not paid enough attention to the children and their families who have been affected both psychologically and economically. The objectives of establishing special boarding schools for children of ex-terrorist children are:

- Accurately record the number of children of former terrorist convicts throughout Indonesia, especially those who are still of school age, dropped out of school or who cannot continue their education due to economic factors.

- Providing compensation and living expenses, children of terrorists who were left by their fathers.

- Making coaching activities ranging from life skills so that they can live independently, educational scholarships to psychiatric rehabilitation due to the loss of father / husband and add confidence because of negative stamp imposed on them.

- Fortifying terrorist / former terrorist children from ideological influences or invitations that trap them to sympathize or be interested in terrorism activities. 
- Provide materials, learning materials or books that children can use in learning to prevent the threat of terrorism in the young generation. Such materials have a positive influence in destroying the seeds and ideology of terrorism in Indonesia. "

\subsection{Founding of Children of Former Therorist}

The system of fostering former terrorists at Al-Hidayah Islamic Boarding School in Sunggal Deli Serdang District is by deradicalizing radical and extreme views that have the potential of terrorists that encourage violence, both physical and psychological violence. There are at least three elements in a terrorist act: 1) the creation of fear in society. 2) there is a belief that his actions are for a higher purpose. 3) that goal is conveyed through physical violence targeting civilian safety. Terrorism is always synonymous with terror, violence, intimidation so often it has negative consequences for many people. Haryatmoko believes that there are at least three reasons why religion has always been a possibility to be used as a basis and justification for acts of violence committed by terrorists. First, it is because of the function of religion as an ideology. In the case of religion being the glue of unifying the nation rather than dividing the community if a society is wrong in providing a framework of interpretation in the meaning of relations between humans, then humanity considers social order as a measure of religious representation of someone who practices the teachings desired by God. Furthermore, on one hand it can cause many contradictions, especially regarding the issue of injustice and social inequality, giving birth to acts of violence. Secondly, religion is used as an identity factor, in the sense that religion specifically gives human authority about the status that exists in him such as the way of life including, ways of thinking, etc. which is very likely to give birth to violence and here religion is very likely to be included too. Third, the function of religion as ethnic legitimacy of relations between people. Unlike religion as a framework of interpretation, this mechanism is not a sacralization of relations between people, but a relationship between people who have the support and legitimacy of religion. "

\subsection{Curriculum Development and Radical and Terrorist Understanding}

Coaching curriculum in the provision of radical and terrorist understanding in al Hidayah Islamic Boarding School researchers generally see a lot of positive views from the existing curriculum at al-Hidayah Islamic Boarding School, in addition to the national curriculum, there is also a central curriculum and also a local curriculum that contains about deradicalization which is taught every Saturday., not only for students but also people outside the al-Hidayah pesantren, especially in the eradication of former terrorist children and children, namely by deradicalizing and educating young generations of terrorist families so that they do not follow the footsteps of their parents becoming theorists, but by provide a comprehensive understanding of religion so that they are not trapped or follow the terrorist movement. As it is known that radical groups and terrorists always oppose democratic ways of organizing life together. Therefore concrete support for the democratization process in Indonesia will greatly assist in suppressing radical groups. Because no matter how radical the ideology of a movement is, if they respect the principles of democracy which include the principles of law and human rights, then it is no longer radical. Because the principle of democracy teaches people to consult or negotiate in regulating public areas. The principle of democracy teaches people to be able to accept only part of what they want.

Another aspect developed by al-Hidayah Islamic boarding school is trying to teach Islam in its entirety including aqeedah, worship and morals or faith, Islam and ihsan. As is believed, 
some Muslims who are trapped in radical movements occur because this group does not comprehend Islam comprehensively. They become radical because of the results of a momentary indoctrination. "So if they have the opportunity to develop aspects of their intellectualism and also aspects of their spiritualism, then they will naturally abandon radical understanding. It is important to introduce Arabic grammar and jurisprudence to students, but that alone is not enough and also the uniqueness of al Hidayah boarding school besides teaching students to learn religious sciences and general sciences and deradicalization education, which is taught to students and also the people in outside the pesantren which was directly delivered by the Chairman of the al-Hidayah Islamic Boarding School Ustad Khairul Ghazali.And this deradicalization education has been going on for quite a long time, and the results are also very satisfying, and many people know about the dangers of radicalism, isis, and terrorism which distress people in particular, but unfortunately Deradicalisation Education activities in the pesantren according to Mr. Haris Iskandar, And these activities goes according to what is in the al-Hidayah Islamic boarding school program, "the higher a person's knowledge or insight, the more he can be inclusive, moderate or tawasuth, and ultimately create rahmatan lil alamin in this world.

\subsection{Kyai's Personality Figures}

The fundamental difference between pesantren in general with al-Hidayah pesantren is in the figure of kiyainya pesantren al-Hidayah which is a former terrorist, because the pesantren that he founded is accommodating former terrorist children scattered throughout Indonesia, and the children are children who are bullied in the neighborhood where he lives, or children who do not get attention, if this is left then the child will follow the footsteps of his parents and become terrorists. To break this link, the children must be educated and re-taught about the correct understanding of the teachings of the Islamic in the version of Ustad Khairul Ghazali. The figure of the kyai Khairul Ghazali always made his students realize that they would live independently and not depend on their parents or the people they had hoped for to bear their lives since their parents left them. The independent life taught at the al-Hidayah boarding school is a way to plant crops that are fast harvesting; growing sweet potatoes, corn, beans or others. It also teaches students how to live modestly, do not need to be lavish in worldly matters, but encourage their students to love the life of their ukhrawi, because this life of ukhrawi is real life.

\subsection{Love of motherland (Nationality)}

Every August 17 is always celebrated as the birth of the beloved republic of Indonesia in 1945 , and this is a historic day for the people of Indonesia in maintaining and fighting for and proclaiming Indonesian independence by Indonesian proclaimers Soekarno, and August 17 became a very sacred moment. marked by the raising of the red and white flags of each house and also banners to enliven the independence day of the Republic of Indonesia. There is a unique way in al-Hidayah Islamic Boarding School every August 17, there are some figures from BNPT and former terrorists present to enliven the independence activities of the Republic of Indonesia each year. Their presence makes the atmosphere warmer and full of intimacy, and this is rarely done in existing boarding schools, their presence gives new enthusiasm to fill the struggle for Indonesian independence, and that makes the atmosphere more emotional, Pesantren al Hidayah actually wants to inculcate its students for the love of the motherland is 
part of faith, with love for the motherland means they are ready to sacrifice themselves to defend against those who want to colonize it.

\subsection{Establishes Peace Gallery}

Al Hidayah Islamic Boarding School is also equipped with a Peace Gallery. This gallery is also a place for the public to find out the dangers of acts of terrorism and provide awareness and early prevention processes. The Peace Gallery aims to: first; displaying photographs of damage and consequences caused by radicalism and terrorism movements; damage and destruction caused by the bombing of public facilities and suicide bombings carried out by radicals in a crowd. Information about the destruction of public facilities and infrastructure as well as fatalities resulting from it, as a medium of awareness to students not to do the same with their parents. Second; display photos or pictures that tell the story of national and state life; aims to foster awareness of students that in the context of the state; Indonesia consists of various ethnic groups, customs, religions and so on. Diversity must be framed by an awareness of accepting the presence of other people who are different and respect each other. Third; dislaying religious books of moderate nuance; reinterpretation of classical terminology that is often used by certain parties to legitimize the behave of extremism. In addition to the citizenship books that guide citizens to recognize diversity, but one within the framework of statehood, namely the Republic of Indonesia Unitary State.

\section{Conclusion}

From the discussion above it can be understood that the al-Hidayah Islamic Boarding School was used as a barometer in counteracting radical understanding. This pesantren is the only pesantren that can be used as the basis for deradicating radical ideologies that deviate from Islamic teachings. The uniqueness of this al-Hidayah Islamic Boarding School compared to other pesantren is its local content which teaches de-radicalization to its students and also people outside the pesantren, aiming that they understand about the dangers of radical thought, which can cause danger to innocent people. To counter radicalism and terrorism, ustad Khairul Ghazali is as much as a figure who understands radicalism, and people who are exposed to Isis, then ustad al-Ghazalilah is a figure of a former terrorist who can optimize the role of pesantren in counteracting radicalism and terrorism movements, by improving the insights of pesantren through more comprehensive studies that not only involve the thought of aqeedah and fiqh but also concerning philosophical and Sufism thinking. The al-Hidayah Islamic boarding school also introduced a more inclusive, accommodating and tolerant theology. The development of a democratic culture that receives high support from pesantren needs to be maintained and further developed by strengthening theological reasons that can be used to deradikalisai terrorist movements in North Sumatra in general.

\section{References}

[1.] Abd Moqsith Ghazali, Argumen Pluralisme Agama: Membangun Toleransi Berbasi Alquran, Depok: KataKita, cet II, 2009.

[2.] Abdul Muis Naharong, Fundamentalisme Islam, Jurnal Universitas Paramadina, Vol. 4 No.1 Juli 2005

[3.] Abdullah Saeed, Islamic Though: An Introduction, 2006, New York: Routledge. 
[4.] Alwi Sihab, Membendung Arus: Respon Gerakan Muhammadiyah Terhadap Penetrasi Misi Kristen di Indonesia, Bandung: Mizan, cet I, 1998.

[5.] Assyaukanie, Luthfi, Ideologi Islam dan Utopia, (Jakarta: Freedom Institute, 2011).

[6.] Basya, Hilaly dan David Alka, Amerika Perangi Teroris Bukan Islam, (Jakarta: Center for Moderate Moslem (CMM), 2004), p. 76.

[7.] Budi Winarno, Isu-Isu Global Kontemporer, (Jakarta: CAPS, 2011).

[8.] Chandra Muzaffar, Muslims, Dialogue Teror, terjemahan, Muslim Dialog dan Teror, Jakarta: Profetik cet. I, 2004.

[9.] Edwards, Beverley Milton, Islam and Violence in the Modern Era (New York: Palgrave Macmillan, 2006).

[10.] Effendy, Bahtiar, Islam dan Negara, Transformasi Gagasan dan Praktik Politik Islam di Indonesia (Jakarta: Yayasan Abad Democrasi) Edisi Digital.

[11.] Farhad Daftary ed, Intellectual Traditions in Islam, terjemahan, Tradisitradisi Intelektual Islam, Jakarta: Erlangga, cet I, 2001.

[12.] Fata, Badrus Syamsa (ed), Agama dan Kontestasi Ruang Publik, (Jakarta: The Wahid Institute, 2011).

[13.] Fathi Yakan, Nahwa Masyru' Islamy Rasyid) terjemahan Islam Era Global: Kajian Proyek Islamisasi Ideal, Yogyakarta: Ababil, cet I, 1996

[14.] Fukuyama, Francis, The End of History (Terj) (Yogyakarta: Qolam, 2005).

[15.] Harvey W. Kushner, Encyclopedia of Terrorism, London: Sage Publication, 2003.

[16.] Hendropriyono, Terorisme: Fundamentalisme Kristen, Yahudi dan Islam, (PT. Kompas Madia Nusantara, Jakarta, 2009)

[17.] Huntington, Samuel, Authoritarian Politics In Modern Society, (Gramedia Pustaka, Jakarta, 1996).

[18.] Huntington, Samuel, Benturan Antar Peradaban dan Masa Depan Politik Dunia, (Yogyakarta: Penerbit Qalam, 1996).

[19.] Karen Amstrong, The Battle for God: Fundamentalism in Judaism, Christianity and Islam. (New York: Ballantine, 2000).

[20.] Katimin, Mozaik Pemikiran Islam: Dari Masa Klasik Sampai Masa Kontemporer, Medan: Perdana Mulya Sarana, cet I, 2010.

[21.] Khairul Ghazali, Aksi Perampokan Bukan Fa'i, Jakarta: Grafindo Khazanah Ilmu, cet I, 2011.

[22.] Khairul Ghazali, Aksi Teror Bukan Jihad: Membedah Ideologi Takfiri dan Penyimpanagan Jihad di Indonesia, Jakarta: Daulat Press cet I, 2015.

[23.] Khamami Zada dan Arif R. Arafah, Diskursus Politik Islam, (Jakarta: LSIP, 2004).

[24.] Kumar Ramakhrisna, Radical Pathways: Understanding Muslim Radicalization in Indonesia, London: Praeger Security International, 2009.

[25.] M. Amin Abdullah, Studi Agama Normatovitas Atau Historisitas, Yogyakarta: Pustaka Pelajar, cet I, 1996.

[26.] M. Quraish Shihab, Wawasan Alquran: Tafsir Maudhui Atas Berbagai Persoalan Umat, Bandung: Mizan, 1996.

[27.] Mastuhu, Dinamika Pendidikan Pesantren: Suatu Kajian Tentang Unsur dan Nilai Sistem Pendidikan Pesantren,. Jakarta: INIS, 1994.

[28.] Muhammad Mustofa, Krimininologi, Kajian Sosiologi terhadap Kriminalitas, Perilaku Menyimpang dan Pelanggaran Hukum, (Jakarta: FISIP UI Press, 2007).

[29.] Muzaffari, Mehdi, Kekuasaan Dalam Islam, Terj. Abdurrahman Ahmed, (Jakarta: Pustaka Panjimas, 1994).

[30.] Nurcholish Madjid, Pintu-Pintu Menuju Tuhan, Jakarta: Paramadina, cet VIII, 2008. 107

[31.] Permata, Ahmad Norma, Agama dan Terorisme, (Surakarta: Muhamadiyah University Press, 2006)

[32.] Rakhmat, M. Imdadun, Arus Baru Islam Radikal: Transmisi Revivalisme Islam Timur Tengah ke Indonesia, (Jakarta: Erlangga, 2007).

[33.] S. Hamid Hasan, "Pendekatan Multikultural untuk Penyempurnaan Kurikulum Nasional", Kompas, 2003.

[34.] Saidurrahman dan Arifinsyah, Nalar Kerukunan: Merawat Keragaman Bangsa Mengawal NKRI, Medan: Perdana Publishing, cet I, 2018. 
[35.] Sarlito Wirawan Sarwono, Program Re-edukasi untuk Para Tahanan atau Napi Teroris, Depok: Universitas Indonesia.

[36.] Sayyid Quthb, Fi Zhilal al-Qur'an, Beirut; 1987.

[37.] Syahrin Harahap, Upaya Kolektif Mencegah Radikalisme dan Terorisme, (PT. Desindo Putra Mandiri, 2017)

[39.]

, Islam Menolak Terorisme, 2015, Medan, UNIVA Press

$[40$. , Menjaga Harmonitas; Pengalaman Islam, 2006, Medan

[41.] Tariq Ramadhan, To be European Muslim: A Study of Islamic Sources in the Eouropean Context, terjemahan Teologi Dialog Islam-Barat: Pergumulan Muslim Eropa, Bandung: Mizan, cet I, 2002.

[42.] Tibi, Bassam, Ancaman Fundamentalisme: Rujukan Islam Politik dan kekacauan Dunia Baru, (PT. Tiara Wacana Yogja, 2000)

[43.] Tinka Veldhuis dan Jørgen Staun, Islamist Radicalisation: A Root Cause Model, Den Haag: Netherlands Institute of International Relations Clingendael, 2009.

[44.] Turmudi, Endang, dkk, Islam dan Radikalisme di Indonesia, LIPI Press, 2005

[45.] Wiktorowicz, Quintan (ed), Aktivisme Islam dan Teori Gerakan Sosial, (Jakarta; Yayasan Abad Demokrasi), edisi Digital. 